Supporting Information for

\title{
New Generation Oxyntomodulin Peptides with Improved Pharmacokinetic Profiles Exhibit Weight Reducing and Anti-steatotic Properties in Mice
}

Peng-Yu Yang, ${ }^{\dagger, \ddagger, \S}$ Huafei Zou, ${ }^{\dagger, \S}$ Zaid Amso, ${ }^{+, \S}$ Candy Lee, ${ }^{\dagger}$ David Huang, ${ }^{\dagger}$ Ashley K. Woods, ${ }^{\dagger}$ Vân NguyenTran, ${ }^{\dagger}$ Peter G. Schultz, ${ }^{,+,+\ddagger}$ Weijun Shen ${ }^{*}{ }^{+}$

${ }^{+}$Calibr at The Scripps Research Institute, La Jolla, CA 92037, United States.

${ }^{\ddagger}$ Department of Chemistry, The Skaggs Institute for Chemical Biology, The Scripps Research Institute, La Jolla, CA 92037, United States

\section{Materials and General Procedures}

All cysteine mutant peptides, exendin-4, glucagon, OXM-1 and semaglutide were purchased from Innopep (San Diego, CA; greater than 95\% purity). In addition to quality control data supplied with peptide purchased, all peptides were characterized in-house using ESI-MS. The preparation of cross-linkers L1 - L5 have been previously described. ${ }^{1,2}$ Solvents and chemicals were purchased from the commercial sources and used directly without further purification. Electrospray Ionization Mass Spectrometry (ESI/MS) was performed on Agilent G1946C 1100.

\section{Peptide cross-linking}

The cross-linking reaction was carried out by incubating the dicysteine-containing peptides ( 2 mM) (Innopep, San Diego, CA; greater than 95\% purity) with 1.5 equiv of cross-linkers in a mixed solvent solution (1:3 $\mathrm{CH}_{3} \mathrm{CN} / 30 \mathrm{mM} \mathrm{NH}_{4} \mathrm{HCO}_{3}$ buffer, $\mathrm{pH}$ 8.5). The mixture was stirred at 
RT for 2-4 hours. Under ice cooling, acetic acid was then added dropwise to pH 5. Crude crosslinked peptide was then purified by preparative HPLC column (Phenomenex, Prep C18, 300A, 50 x $250 \mathrm{~mm}$ ) with a linear gradient from $20 \%$ to $80 \% \mathrm{CH}_{3} \mathrm{CN} / \mathrm{H}_{2} \mathrm{O}$ containing $0.05 \%$ trifluoroacetic acid for $30 \mathrm{~min}$ at a flow rate of $15 \mathrm{~mL} / \mathrm{min}$. The fractions containing the products were collected and lyophilized to afford the products as a powder with $>95 \%$ purity and in $>70 \%$ product yield. Their identity was confirmed by ESI-MS and MALDI-TOF. Analytical HPLC was performed using an Agilent 1100 series LC/MS system with a ZORBAX C18 column $(5 \mu \mathrm{m}, 150 \times$ $4.6 \mathrm{~mm}$ ) from Agilent with a linear gradient of $10-70 \%$ acetonitrile/water containing $0.1 \%$ formic acid for $20 \mathrm{~min}$ at a flow rate of $1.0 \mathrm{~mL} / \mathrm{min}$ with UV-vis detection wavelength set at 214 and $254 \mathrm{~nm}$.

\section{Generation of CRE-Luc stable cell line over-expressing GLP-1 or GCG receptor}

HEK293 cells were infected with lentivirus encoding firefly luciferase gene under the control of cAMP responsive element (CRE) promoter (Qiagen, Netherlands) and then were selected using $1 \mu \mathrm{g} / \mathrm{mL}$ puromycin (Life technologies, Carlsbad) for 1 week. The surviving cells (referred to as CRE-HEK293) were expanded and then transfected with a G418 selective mammalian expression plasmid encoding human GLP-1R or GCGR. In brief, GLP-1R or GCGR plasmid was transfected into CRE-HEK293 cells using Lipofectamine 2000 and selected with $400 \mu \mathrm{g} / \mathrm{mL}$ geneticin (Life technologies, Carlsbad, CA). Single colony stable cell line over-expressing both CRE-luciferase and GLP-1R (HEK293-GLP-1R-CRE) or GCGR (HEK293-GCGR-CRE) was then established for in vitro activity assay. 


\section{In vitro receptor activation reporter assay (receptor-mediated cAMP synthesis)}

HEK293-GLP-1R-CRE or HEK293-GCGR-CRE cells were seeded in 384-well plates at a density of 5000 cells per well and cultured for 18 hours in DMEM with $10 \%$ FBS at $37^{\circ} \mathrm{C}$ and $5 \% \mathrm{CO}_{2}$. Cells were treated with peptides in a dose dependent manner for 24 hours, and receptor activation was reported by luminescence intensities, using One-Glo (Promega, WI) luciferase reagent following manufacturer's instruction. The $\mathrm{EC}_{50}$ of each peptide was determined using GraphPad Prism 6 software (GraphPad, San Diego, CA).

\section{Circular dichroism (CD) measurements}

CD spectra were recorded with an AVIV model 420SF CD spectrometer at $25^{\circ} \mathrm{C}$ in a $2 \mathrm{~mm}$ pathlength cuvette. The spectra were recorded in the wavelength range of $190-260 \mathrm{~nm}$ and averaged over 3 scans with a resolution of $0.5 \mathrm{~nm}$, a bandwidth of $1.0 \mathrm{~nm}$ and a response time of $3 \mathrm{~s}$. All peptides were dissolved in water to reach final concentrations of $40 \mu \mathrm{M}$. The mean residue ellipticity was plotted vs wavelength.

\section{Animals and Statistical analysis}

All animal care and experimental procedures were approved by the Institutional Animal Care and Use Committee (IACUC) of California Institute for Biomedical Research (Calibr) and strictly followed the NIH guidelines for humane treatment of animals. The results are expressed as means \pm S.E., and the data were compared using the unpaired Student's $t$ test. Where appropriate, data were compared using repeated measures or one-way analysis of variance, followed by the Student-Newman-Keuls post hoc test. Incremental area under the curve (AUC) 
analyses for plasma glucose was calculated using GraphPad Prism 6. Groups of data were considered to be significantly different if $p<0.01$.

\section{Pharmacokinetics of peptides in mice}

Female CD-1 mice $(\mathrm{N}=4)$ from Charles River Laboratory were fasted overnight and administrated with $100 \mu \mathrm{L}$ of each peptide in phosphate buffered saline by intravenous (i.v.) or subcutaneous (s.c.) route. Food was provided to mice immediately after bleeding at 3 h. Blood was extracted into heparin tubes and centrifuged at 3,000x g for $15 \mathrm{~min}$. The resulting supernatant plasma were then stored at $-80{ }^{\circ} \mathrm{C}$ for peptide concentration determination. The concentrations of peptides in plasma at each time point were determined by in vitro cell based activity assay. Briefly, HEK293-GLP-1R-CRE cells were treated with plasma samples at different time points (5 point dose response, starting from 1:10 to 1:100 dilution of each plasma sample) and incubated for 16 hours in DMEM with $10 \% \mathrm{FBS}$ at $37{ }^{\circ} \mathrm{C}$ with $5 \% \mathrm{CO}_{2}$, and the firefly luciferase activity was then measured. At the same time, same peptides were used to obtain standard curves and parameters for Bottom, Top, EC 50 , and Hill Slope. Random luciferase unit (RLU) for each plasma sample was used to calculate the peptide concentrations in plasma $(\mathrm{nmol} / \mathrm{L})$, using parameters derived from the standard curve $(\mathrm{RLU}=$ Bottom $+($ Top-Bottom $) /(1$ $+10^{(\operatorname{logEC} 50-\text { conc)*Hill Slope })}$. Peptide concentrations in plasma were obtained and plotted against time points to obtain in vivo half-life of each peptide, using WinNonLin Phoenix software (Pharsight Corp, St. Louis, MO). 


\section{Oral glucose tolerance test (OGTT)}

Female Charles River CD-1 mice were fasted overnight and then administrated with $100 \mu \mathrm{L}$ of each peptide in PBS $(\mathrm{pH}=7.3)$ by i.v. or s.c. route. After 6 hours, mice were orally or intraperitoneally administrated with $2 \mathrm{~g}$ of glucose solution per $\mathrm{kg}$ body weight and their tail blood glucose levels were measured before $(0 \mathrm{~min})$ and after glucose challenge for 2 to 3 hours.

\section{Body weight, food intake, and visceral fat mass measurement}

DIO mice (C57BL/6, male, 25-week old, or 19 weeks on high fat diet) were randomized based on their body weight and were treated with daily subcutaneous injections of peptides or vehicle (n $=5$ ). Body weight and food intake were monitored daily throughout the study. At the end of the experiment, mice were sacrificed, and visceral fat mass were weighed.

Collected plasma was used for cholesterol level determination according to the manufacturer's guide (cholesterol assay kit, Abcam, Cambridge, England) and triglyceride level using a triglyceride colorimetric assay kit (Cayman chemical, Ann Arbor, Michigan).

\section{Oil red $O$ staining (Lipid droplet staining)}

Frozen tissue sections of liver were cut at $10 \mu \mathrm{m}$ and air dried onto the slides. After fixation in $10 \%$ formalin for $5 \mathrm{~min}$, the slides were briefly washed with running tap water for $10 \mathrm{~min}$, followed by rinse with $60 \%$ isopropanol. Subsequently, oil red 0 working solution $(0.3 \%$ oil red O) was used to stain lipid for 15 min. Slides were again rinsed with $60 \%$ isopropanol and then nuclei were lightly stained with alum hematoxylin, followed by rinse with distilled water and mounted in glycerin jelly. Pictures were taken under microscopy. 


\section{CDAA-induce NASH mice}

Male C57BL/6 mice ( $n=9$ per group) from the Jackson Laboratory (Bar Harbor, ME; age 5 weeks) were maintained in a controlled environment $\left(12 \mathrm{~h}\right.$ light/dark cycle; temperature $21-22{ }^{\circ} \mathrm{C}$; humidity $50 \pm 10 \%$ ). After one week of acclimation, mice were randomized into groups with ad libitum access to water and specialized diets: either choline-supplemented L-amino-acid defined diet (CSAA, catalog \#518754, Dyets Inc., Bethlehem, PA) or choline-deficient L-amino acid-defined diet (CDAA; catalog \#518743; Dyets Inc.) for 12 weeks of diet induction. Animals were randomized based on serum alanine aminotransferase (ALT), aspartate aminotransferase (AST) and body weight into treatment groups and mice were treated daily with either vehicle (saline) or with semaglutide $(40 \mu \mathrm{g} / \mathrm{kg})$ and $014(40 \mu \mathrm{g} / \mathrm{kg})$ subcutaneously for 4 weeks. Body weights were recorded weekly throughout the study. At the end of study, mice were sacrificed and bled to collect terminal serum sample and wet liver weight for further analyses.

\section{Biochemical and Histological analyses}

Terminal serum analytes including alanine aminotransferase (ALT), aspartate aminotransferase (AST), alkaline phosphatase (ALP) were determined by Alfa Wassermann Vet Axcel clinical analyzer. Hepatic triglycerides were measured in liver homogenates with a colorimetric triglyceride kit (Cayman Chemical). Paraformaldehyde-fixed liver were paraffin-embedded, sectioned and stained with hematoxylin-eosin and Picro-Sirius red by HistoTox Labs (Boulder, CO). All histological assessment (steatosis, fibrosis scoring) were performed by a certified histopathologist blind to treatment (HistoTox Labs) based on classification outlined by Kleiner et al. ${ }^{3}$ 


\section{References}

1. Yang, P. Y., Zou, H., Lee, C., Muppidi, A., Chao, E., Fu, Q., Luo, X., Wang, D., Schultz, P. G., and Shen, W. (2018) Stapled, long-acting glucagon-like peptide 2 analog with efficacy in dextran sodium sulfate induced mouse colitis models. J. Med. Chem. 61, 3218-3223.

2. Yang, P.-Y., Zou, H., Chao, E., Sherwood, L., Nunez, V., Keeney, M., Ghartey-Tagoe, E., Ding, Z., Quirino, H., Luo, X., et al. (2016) Engineering a long-acting, potent GLP-1 analog for microstructure-based transdermal delivery. Proc. Natl. Acad. Sci. USA 113, 4140-4145.

3. Kleiner, D. E., Brunt, E. M., Van Natta, M., Behling, C., Contos, M. J., Cummings, O. W., Ferrell, L. D., Liu, Y. C., Torbenson, M. S., Unalp-Arida, A., et al. (2005) Design and validation of a histological scoring system for nonalcoholic fatty liver disease. Hepatology (Baltimore, Md.) 41, 1313-1321. 
Table S1. Characterization of the cross-linked OXM analogs ${ }^{a}$

\begin{tabular}{|c|c|c|c|c|c|c|}
\hline Name & SEQ & Linker & Molecular Weight & Mass found & $\begin{array}{l}\mathrm{EC}_{50}(\mathrm{nM}) \\
\mathrm{GLP}-1 \mathrm{R}\end{array}$ & $\begin{array}{l}\mathrm{EC}_{50}(\mathrm{nM}) \\
\mathrm{GCGR}\end{array}$ \\
\hline 01 & SEQ-1 & $\mathrm{L} 1$ & 4524.1 & $1510.0\left([\mathrm{M}+3 \mathrm{H}]^{3+}\right), 1132.0\left([\mathrm{M}+4 \mathrm{H}]^{4+}\right)$ & 0.03 & 0.2 \\
\hline 02 & SEQ-1 & L2 & 4952.7 & $1651.8\left([\mathrm{M}+3 \mathrm{H}]^{3+}\right), 1239.2\left([\mathrm{M}+4 \mathrm{H}]^{4+}\right)$ & 0.04 & 0.3 \\
\hline 03 & SEQ-1 & L3 & 5038.8 & $1680.3\left([\mathrm{M}+3 \mathrm{H}]^{3+}\right), 1260.6\left([\mathrm{M}+4 \mathrm{H}]^{4+}\right)$ & 2.0 & 3 \\
\hline 04 & SEQ-2 & $\mathrm{L} 1$ & 3489.9 & $1164.4\left([\mathrm{M}+3 \mathrm{H}]^{3+}\right), 873.6\left([\mathrm{M}+4 \mathrm{H}]^{4+}\right)$ & 0.2 & 0.04 \\
\hline 05 & SEQ-2 & $\mathrm{L} 2$ & 3918.5 & $1307.2\left([\mathrm{M}+3 \mathrm{H}]^{3+}\right), 980.6\left([\mathrm{M}+4 \mathrm{H}]^{4+}\right)$ & 0.1 & 0.1 \\
\hline 06 & SEQ-3 & $\mathrm{L} 1$ & 3509.0 & $1170.6\left([\mathrm{M}+3 \mathrm{H}]^{3+}\right), 878.2\left([\mathrm{M}+4 \mathrm{H}]^{4+}\right)$ & 0.03 & 0.03 \\
\hline 07 & SEQ-3 & $\mathrm{L} 2$ & 3937.6 & $1313.6\left([\mathrm{M}+3 \mathrm{H}]^{3+}\right), 985.4\left([\mathrm{M}+4 \mathrm{H}]^{4+}\right)$ & 0.03 & 0.05 \\
\hline 08 & SEQ-3 & L3 & 4065.7 & $1355.6\left([\mathrm{M}+3 \mathrm{H}]^{3+}\right), 1017.3\left([\mathrm{M}+4 \mathrm{H}]^{4+}\right)$ & 0.03 & 0.1 \\
\hline 09 & SEQ-3 & L4 & 4295.0 & $1432.6\left([\mathrm{M}+3 \mathrm{H}]^{3+}\right), 1074.7\left([\mathrm{M}+4 \mathrm{H}]^{4+}\right)$ & 0.05 & 0.5 \\
\hline 010 & SEQ-3 & $\mathrm{L} 5$ & 4296.0 & $1433.0\left([\mathrm{M}+3 \mathrm{H}]^{3+}\right), 1075.1\left([\mathrm{M}+4 \mathrm{H}]^{4+}\right)$ & 0.3 & 1.0 \\
\hline 011 & SEQ-4 & L3 & 4902.6 & $1635.2\left([\mathrm{M}+3 \mathrm{H}]^{3+}\right), 1226.6\left([\mathrm{M}+4 \mathrm{H}]^{4+}\right)$ & 0.04 & 0.4 \\
\hline 0124 & SEQ-4 & L4 & 5129.9 & $1711.0\left([\mathrm{M}+3 \mathrm{H}]^{3+}\right), 1284.2\left([\mathrm{M}+4 \mathrm{H}]^{4+}\right)$ & 0.3 & 0.5 \\
\hline 013 & SEQ-4 & $\mathrm{L} 5$ & 5130.8 & $1711.3\left([\mathrm{M}+3 \mathrm{H}]^{3+}\right), 1283.8\left([\mathrm{M}+4 \mathrm{H}]^{4+}\right)$ & 0.5 & 1 \\
\hline 014 & SEQ-5 & $\mathrm{L} 3$ & 4844.5 & $1615.6\left([\mathrm{M}+3 \mathrm{H}]^{3+}\right), 1212.2\left([\mathrm{M}+4 \mathrm{H}]^{4+}\right)$ & 0.03 & 0.15 \\
\hline 015 & SEQ-5 & L4 & 5073.7 & $1092.2\left([\mathrm{M}+3 \mathrm{H}]^{3+}\right), 1269.4\left([\mathrm{M}+4 \mathrm{H}]^{4+}\right)$ & 0.04 & 0.3 \\
\hline 016 & SEQ-5 & $\mathrm{L} 5$ & 5074.7 & $1692.6\left([\mathrm{M}+3 \mathrm{H}]^{3+}\right), 1269.8\left([\mathrm{M}+4 \mathrm{H}]^{4+}\right)$ & 0.04 & 0.4 \\
\hline 017 & SEQ-5 & L6 & 4915.57 & $1639.5\left([\mathrm{M}+3 \mathrm{H}]^{3+}\right), 1229.8\left([\mathrm{M}+4 \mathrm{H}]^{4+}\right)$ & 0.06 & 0.08 \\
\hline 018 & SEQ-5 & L7 & 5187.87 & $1730.2\left([\mathrm{M}+3 \mathrm{H}]^{3+}\right), 1297.9\left([\mathrm{M}+4 \mathrm{H}]^{4+}\right)$ & 0.91 & 1.4 \\
\hline
\end{tabular}

a Peptides were HPLC-purified to $\geq 95 \%$. 

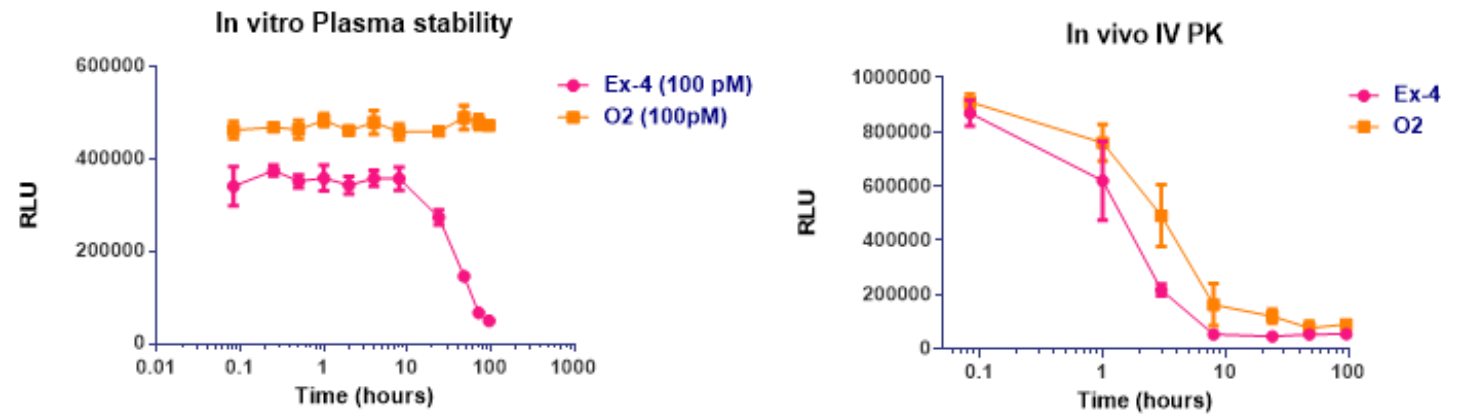

Figure S1. In vitro rat plasma stability and in vivo PK of peptide $\mathbf{0 2 .}$ 


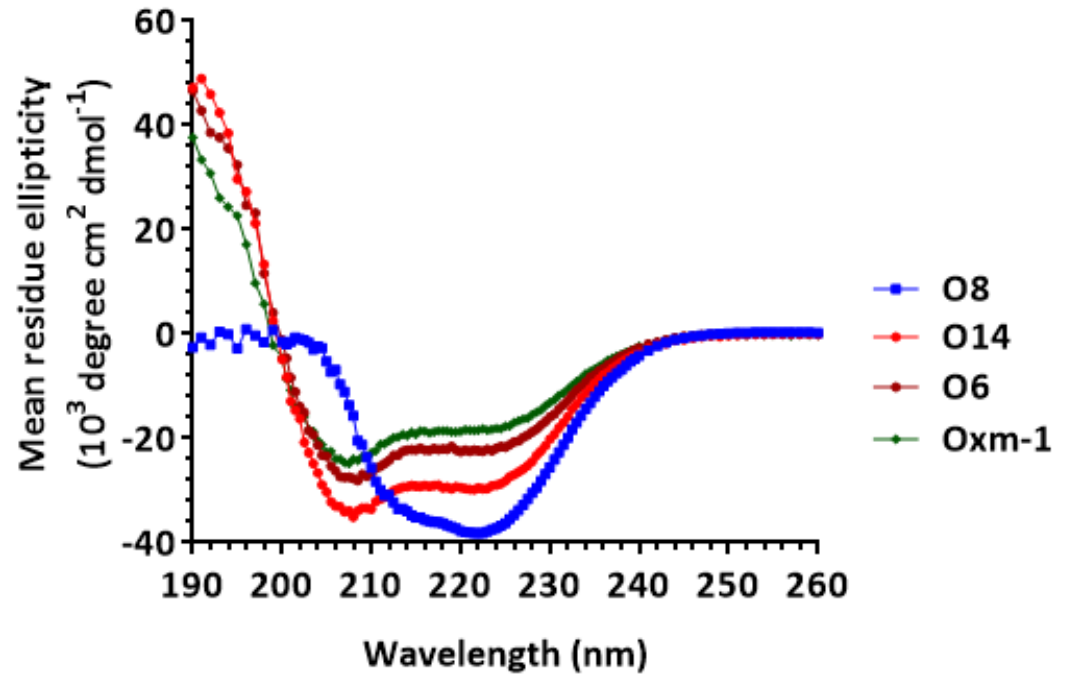

Figure S2. CD analysis of four representative stapled peptides. 
Data File C: \CHEM32\1\DATA \12MAR2015\STD001136.D

Sample Name: OXM-11-Orn-Peg3-C18-LC
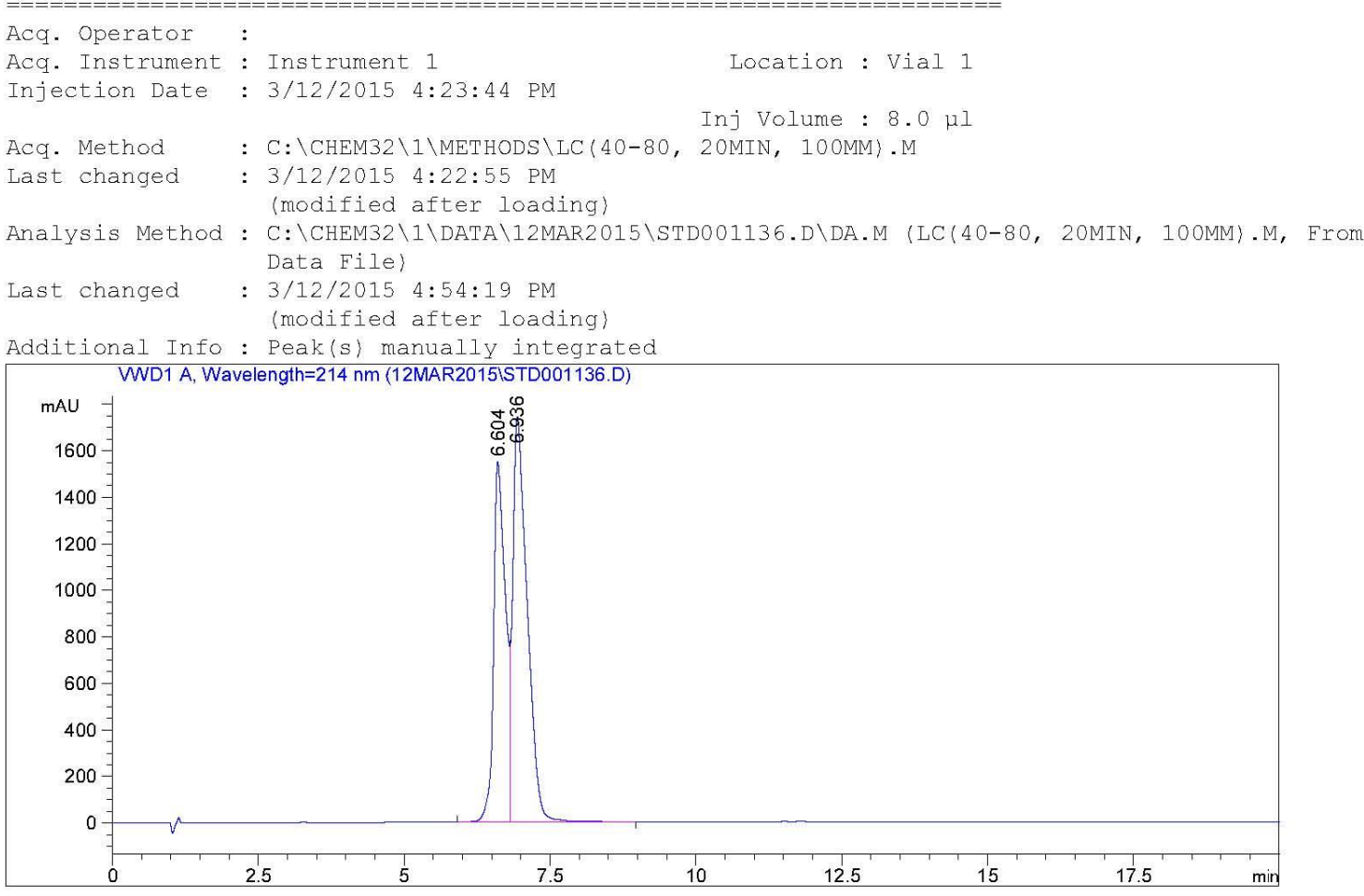

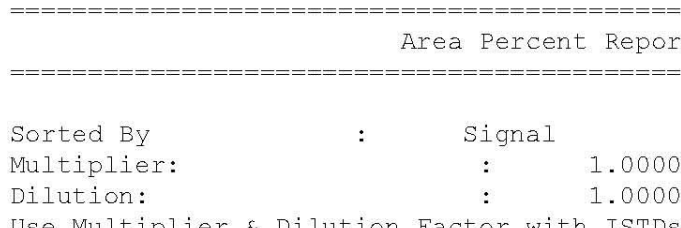

Use Multiplier \& Dilution Factor with ISTD

Signal 1: VWD1 A, Wavelength=214 nm

\begin{tabular}{|c|c|c|c|c|c|c|}
\hline \multirow{2}{*}{$\begin{array}{c}\text { Peak } \\
\#\end{array}$} & \multirow{2}{*}{$\begin{array}{c}\text { RetTime } \\
\text { [min] }\end{array}$} & \multirow[t]{2}{*}{ Type } & \multirow{2}{*}{$\begin{array}{l}\text { Width } \\
\text { [min] }\end{array}$} & Area & Height & \multirow{2}{*}{$\begin{array}{c}\text { Area } \\
\frac{8}{8}\end{array}$} \\
\hline & & & & $\mathrm{mAU} \quad * \mathrm{~s}$ & {$[\mathrm{mAU} \quad]$} & \\
\hline & . & & & ---1 & -- & -------- \\
\hline 1 & 6.604 & VV & 0.1993 & $2.16223 e 4$ & 1548.60388 & 41.6909 \\
\hline 2 & 6.936 & VB & 0.2577 & $3.02410 e 4$ & 1743.21692 & 58.3091 \\
\hline Tota & : & & & $5.18633 e 4$ & 3291.82080 & \\
\hline
\end{tabular}

** End of Report ***

Figure S3. RP-HPLC profile of peptide $\mathbf{0 3}$ 
Print of window 80 : MS spectrum

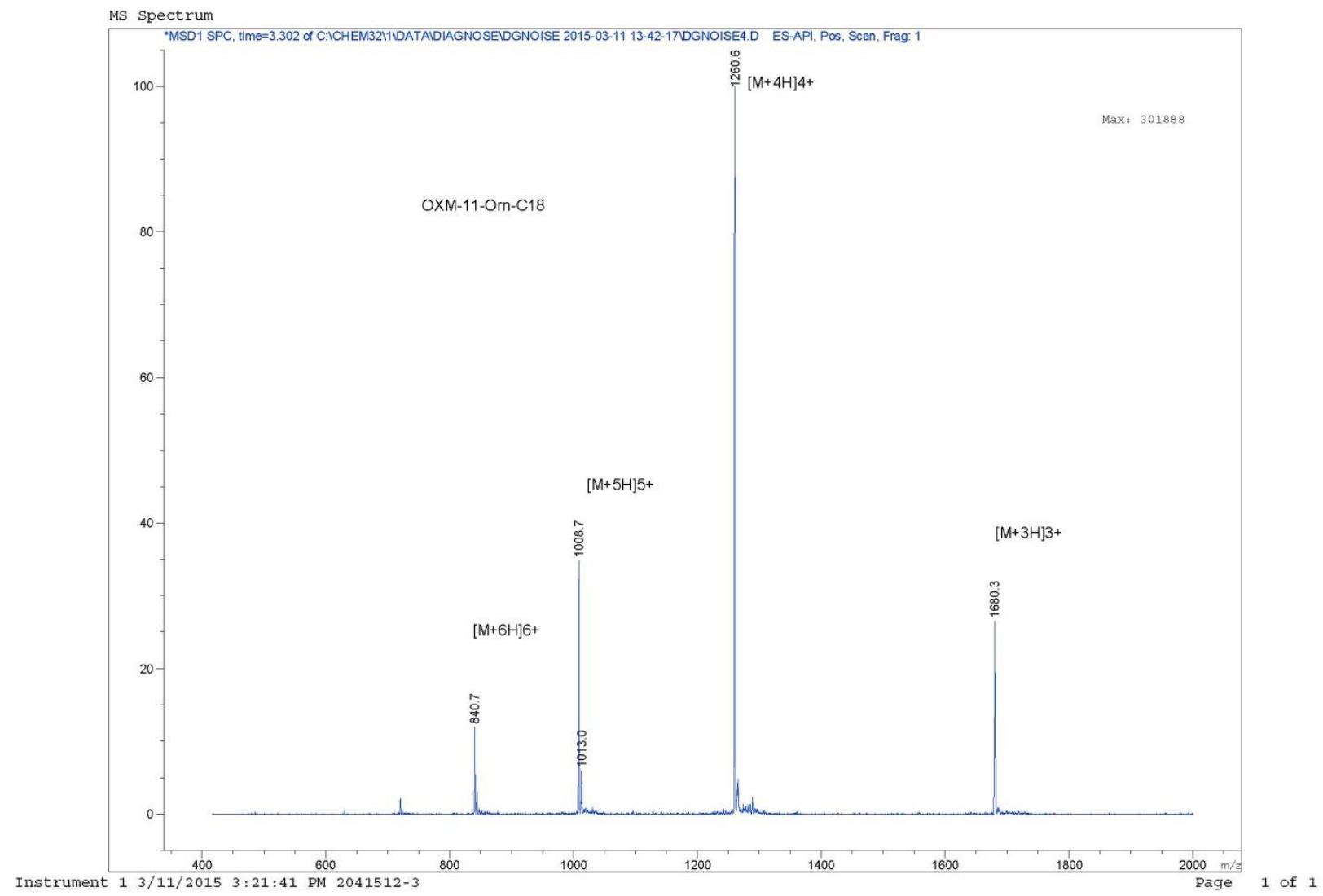

Figure S4. ESI-MS analysis of peptide 03 
Data File C: \CHEM32\1\DATA \12MAR2015\STD001135.D

Sample Name: 25 -Acetate

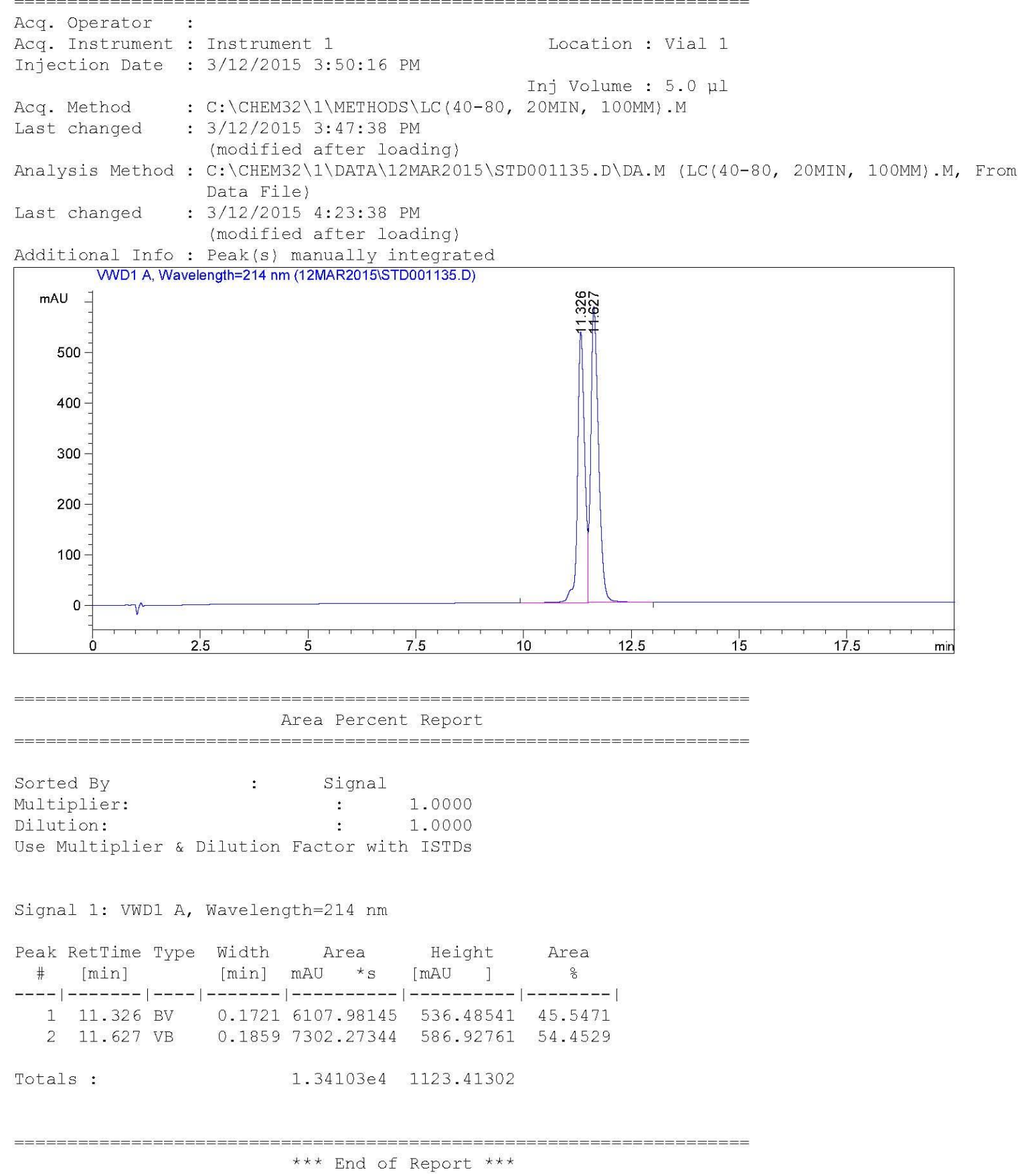

Area Percent Report

\begin{tabular}{|c|c|c|}
\hline Sorted BY & & Signal \\
\hline Multiplier: & & : \\
\hline Dilution: & & : \\
\hline
\end{tabular}

Use Multiplier \& Dilution Factor with ISTDs

Signal 1: VWD1 A, Wavelength=214 nm

\begin{tabular}{|c|c|c|c|c|c|c|}
\hline \multirow{2}{*}{$\begin{array}{c}\text { Peak } \\
\#\end{array}$} & \multirow{2}{*}{$\begin{array}{c}\text { RetTime } \\
\text { [min] }\end{array}$} & \multirow[t]{2}{*}{ Type } & \multirow{2}{*}{$\begin{array}{l}\text { Width } \\
\text { [min] }\end{array}$} & Area & Height & \multirow{2}{*}{$\begin{array}{c}\text { Area } \\
\frac{\circ}{\delta}\end{array}$} \\
\hline & & & & $m A U$ & {$[\mathrm{mAU}$} & \\
\hline-- & ------- & -- & -- & |---------- & ---- & ---- \\
\hline 1 & 11.326 & BV & 0.1721 & 6107.98145 & 536.48541 & 45.5471 \\
\hline 2 & 11.627 & $\mathrm{VB}$ & 0.1859 & 7302.27344 & 586.92761 & 54.4529 \\
\hline Total & : & & & 1. 34103 e 4 & 1123. & \\
\hline
\end{tabular}

\section{Figure S5. RP-HPLC profile of peptide 08}


Print of window 80 : MS spectrum

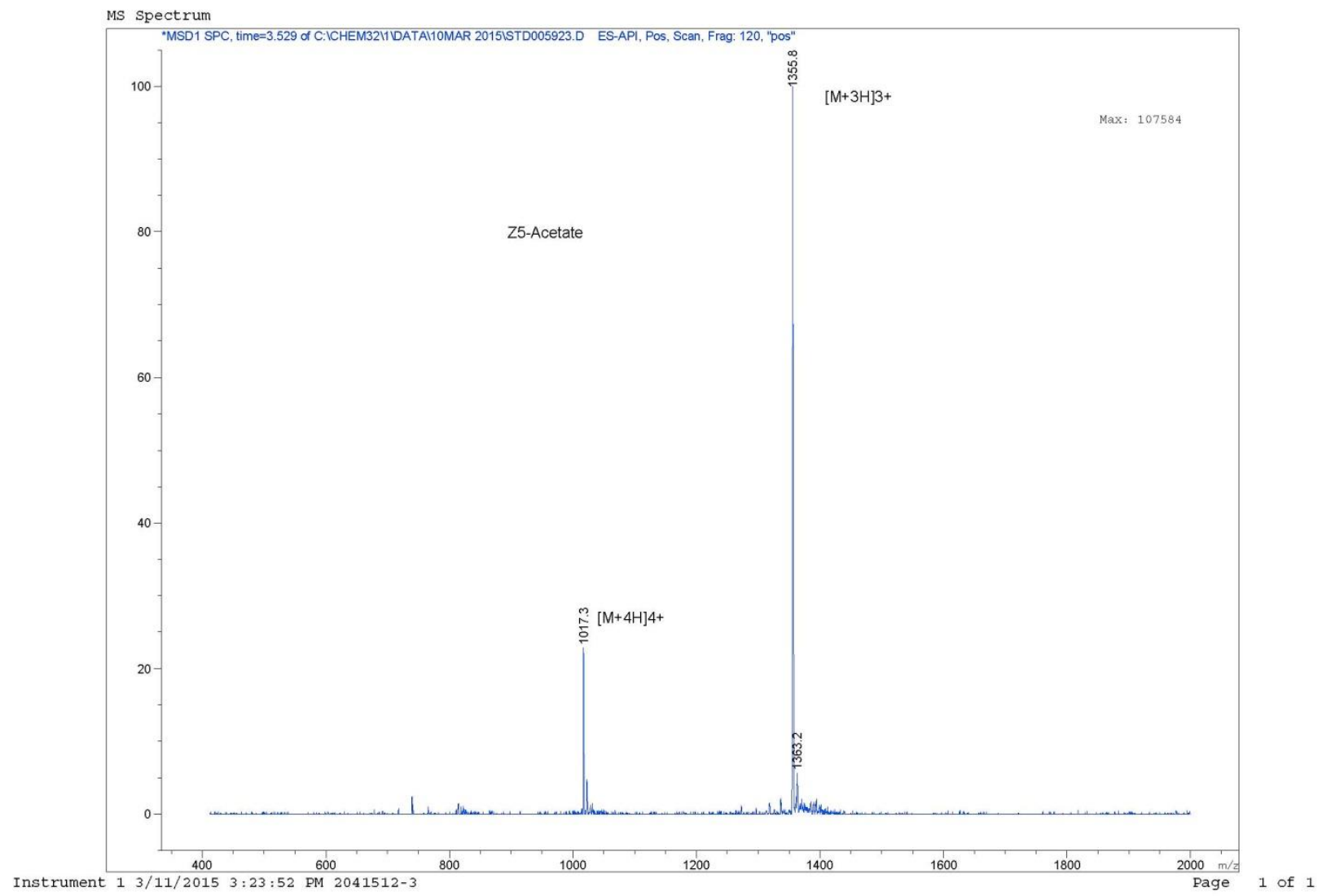

Figure S6. ESI-MS analysis of peptide $\mathbf{0 8}$ 
Data File C: \CHEM32\1\DATA 12MAR2015\STD001138.D

Sample Name: $77-\mathrm{LC}-1$

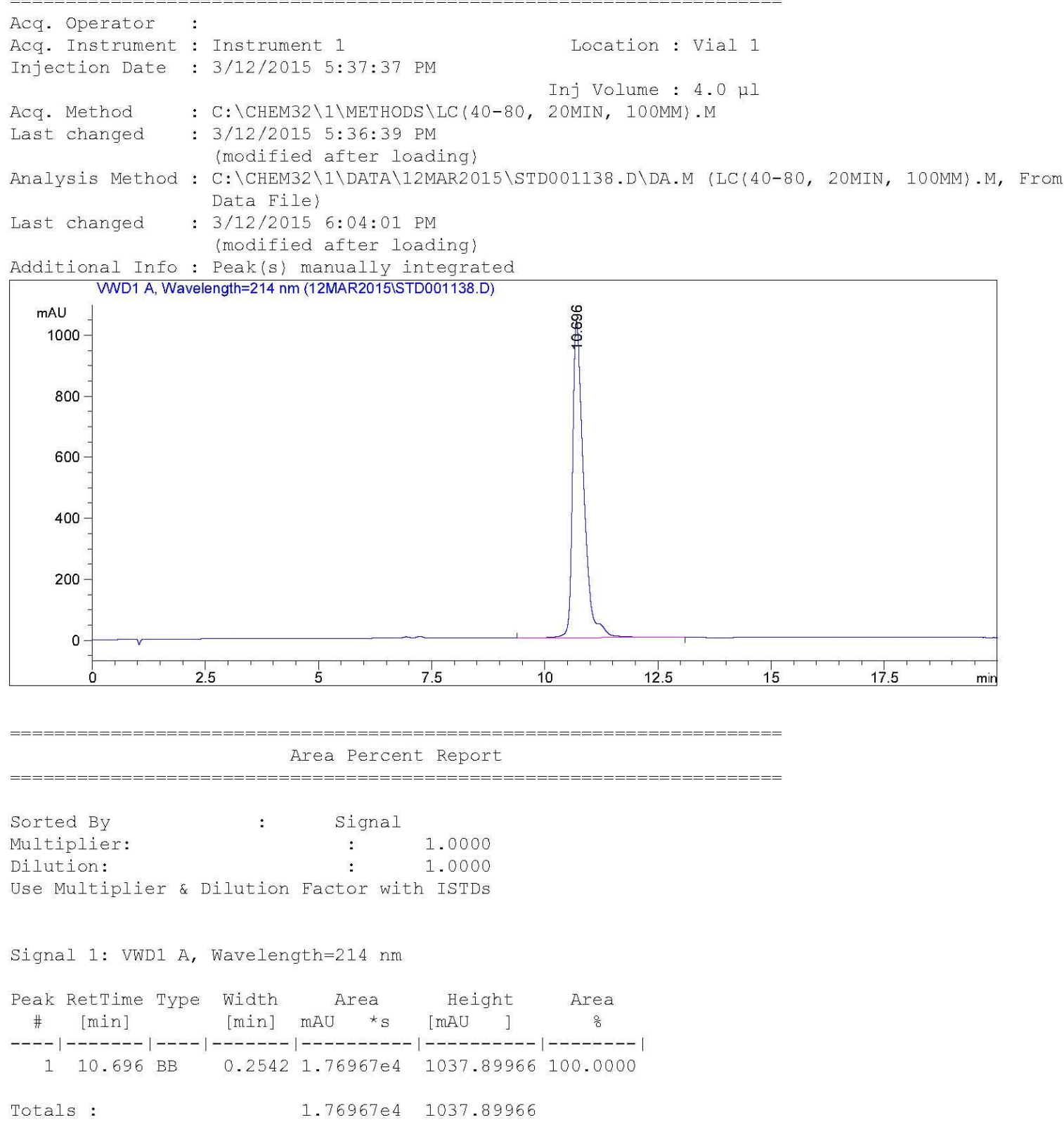

Figure S7. RP-HPLC profile of peptide 014 
Print of window 80 : MS spectrum

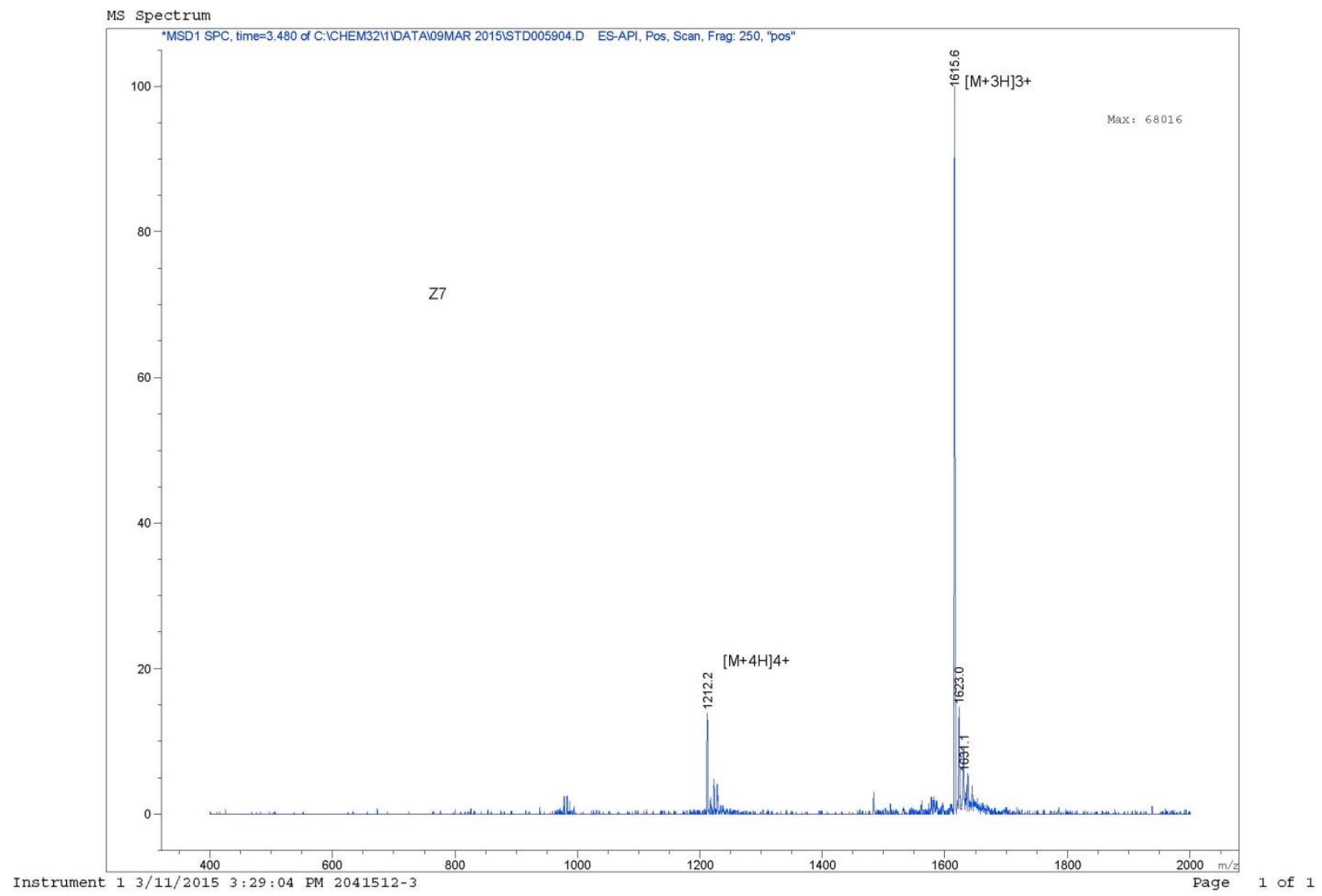

Figure S8. ESI-MS analysis of peptide 014 


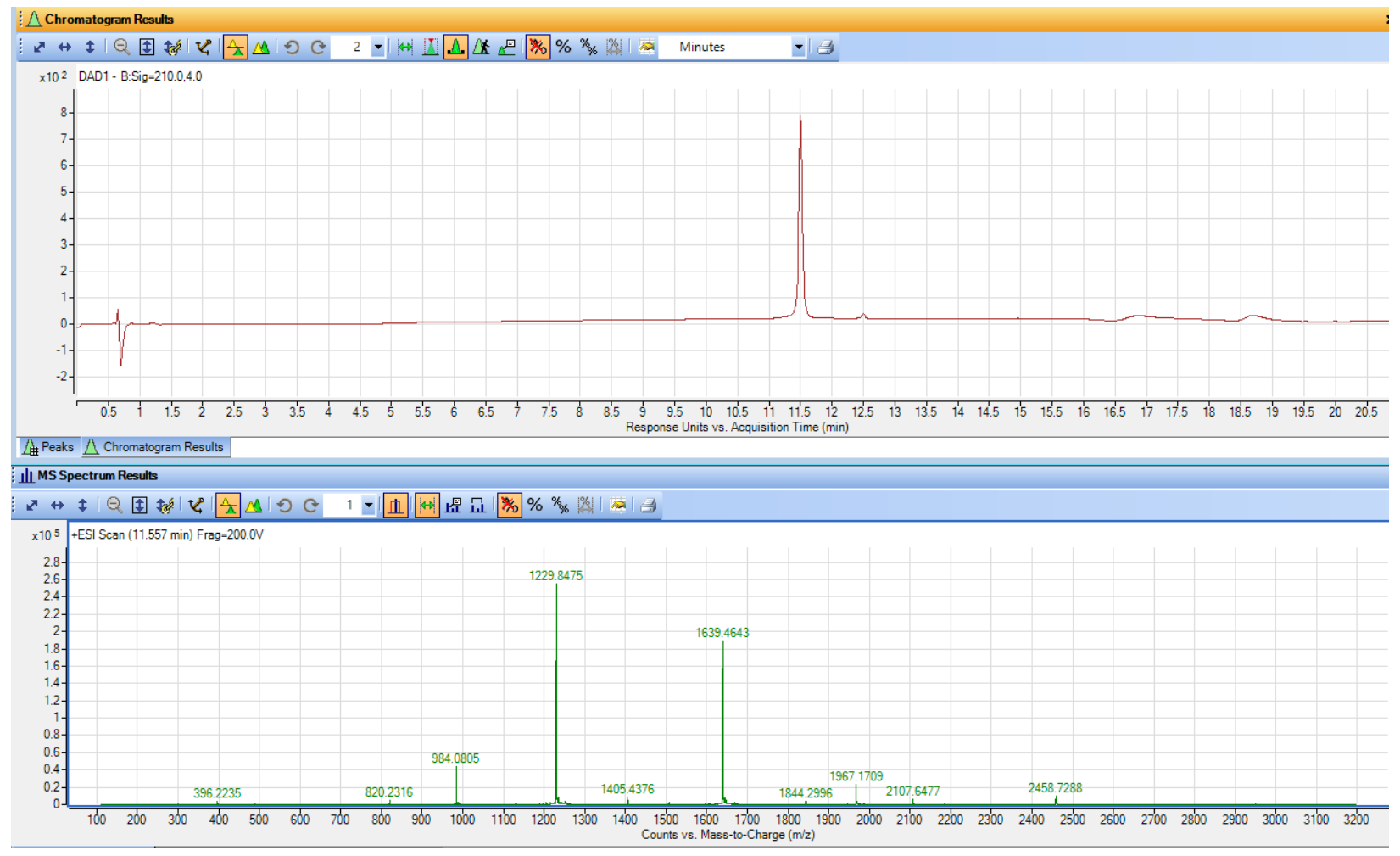

Figure S9. LC-MS analysis of peptide 017

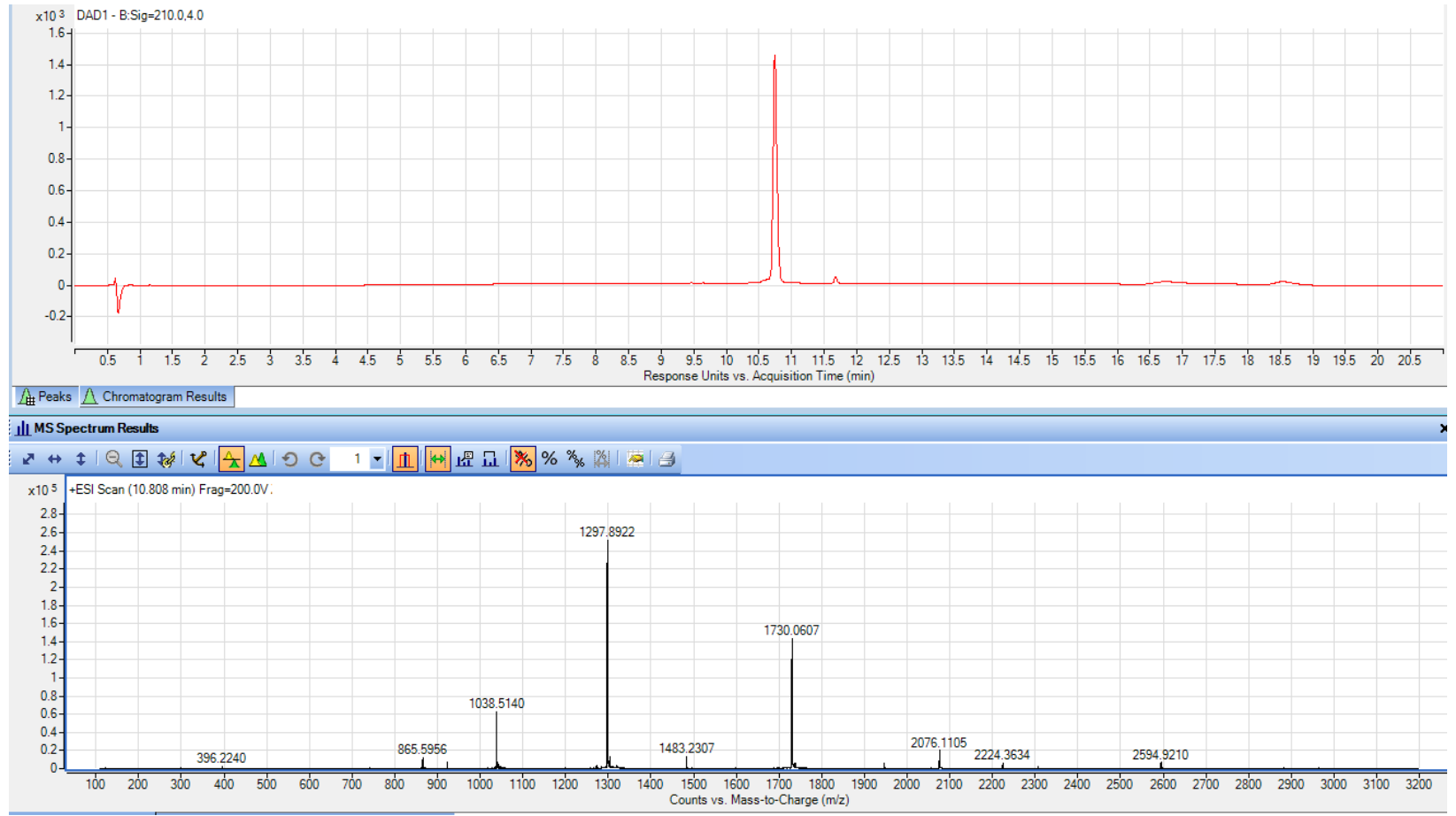

Figure S10. LC-MS analysis of peptide $\mathbf{0 1 8}$ 